\title{
Study of advanced rheumatoid arthritis
}

\author{
Carolina da Silva Carvalho, Luiz Eduardo Coelho Andrade, Silene Peres Keusseyan, João Lucas Rangel, \\ Juliana Ferreira-Strixino, Airton Abrahão Martin, Leandro José Raniero*
}

\begin{abstract}
Introduction: Rheumatic diseases are considered public health problems affecting millions of people worldwide resulting in high and rising health-care costs. In this work, Fourier Transform Infrared spectroscopy associated to Partial Least Square regression (PLS) analysis was used to diagnose rheumatoid arthritis (RA) from human serum. Methods: The sera of 94 individuals were collected, which included 47 from rheumatic patients and 47 from healthy individuals. The results from PLS analysis were compared to standard clinical trials such as anti-citrullinated peptide antibodies, C- Reactive protein, and Rheumatoid factor. Results: For clinical diagnosis, the anti-citrullinated peptide antibodies of second generation proved to be the most specific to diagnosis rheumatoid arthritis even after long periods of drug therapy. Conclusions: The qualitative PLS analysis has shown higher values of IgM of RA group, but the difference was very small. The RA patients were under medication, which interfered with the $\operatorname{IgM}$ concentration.
\end{abstract}

Keywords FTIR spectroscopy, Human serum, Rheumatoid arthritis, Partial Least Square.

\section{Introduction}

Rheumatic diseases are considered public health problems affecting millions of people worldwide resulting in high and rising health-care costs (Cheng et al., 2010; Desai et al., 2010; Waljee and Chung, 2011). For example, in 2003, the United States of America spent a total of 128 billion US\$ on rheumatoid arthritis (RA), which is just one type of rheumatic disease (Birch and Bhattacharya, 2010; Centers..., 2011). Of this sum, 3.6 billion US\$ were spent on drug therapies (Waljee and Chung, 2011) and about US\$ 14,000 on cardiovascular disease associated with an increased prevalence of coronary artery disease present in RA (Desai et al., 2010). In the period from 2007 to 2009, US statistical data indicate an increase of approximately a million of new RA cases per year (Cheng et al., 2010).

RA affects approximately $0.5-1 \%$ of the world population (Hambright et al., 2011; Martínez et al., 2011), being more common in women than in men, and in ages between 40 and 60 years (Ebringer et al., 2010). $\mathrm{RA}$ is the most common systemic autoimmune disease in the world (Haro et al., 2011), and it causes functional disability and premature death. Approximately $70 \%$ of patients have irreversible joint destruction and $80 \%$ of active young adults in the labor market are affected by stiffness and devastating pain (Filipovic et al., 2011). This situation generates a big loss of daily activities and vocational productivity resulting in significant reduction in quality of life (Waljee and Chung, 2011).
Regarding the etiology of the disease, cigarette smoking is described as a possible risk factor for the onset or worsening of RA. Smoking is associated with a worse prognosis of the disease (Karlson and Deane, 2012; Okamoto et al., 2011; Ruiz-Esquide and Sanmartí, 2012). In contrast, little has been said about better eating habits or the benefits of physical activity in this population. The implementation of programs of physical training and nutrition education could provide greater independence and quality of life to RA patients (Külkamp et al., 2009; Plasqui, 2008). Therefore, it is necessary to explore theses parameters within a public health system.

The clinical approach to diagnosis RA is based on the standard procedure established by the ACR (American College of Rheumatology) in 1987. However, this has been widely criticized due to the lack of sensitivity for early detection of the disease. Therefore, the ACR and European League Against Rheumatism (EULAR) has developed a new set of criteria to classify RA based on new laboratory parameters such as anti-citrullinated peptide antibodies (anti-ACPA), C- Reactive protein (CRP), and Rheumatoid factor (RF). The new set of criteria aims to identify early RA patients in order to institute early drug therapy, thereby reducing the functional disability and articular lesions (Aletaha et al., 2010). High concentrations of CRP, RF, and ACPA in serum are associated with unfavorable outcomes, including persistent disease, joint destruction, and functional 
disability. The studies correlating clinical trials (symptoms and signs) with radiographic exams have shown that patients with low titre and/or negative RF/ACPA have a better prognosis (Malaviya et al., 2009). This RF in RA patients may have different classes of gammaglobulins such as $\operatorname{IgM}, \operatorname{IgG}$, or IgA. Nevertheless, classes of IgM and IgG-RF are more correlated with the disease and are abundantly produced by plasma cells in synovial tissue (Duquerroy et al., 2007; Firestein et al., 2009).

The ACR and EULAR have been using these biomarkers as part of the classification criteria for early diagnosis, thereby ensuring the opportunity of early treatment and prevention of irreversible deformities. However, there are some problems in the tests due to the mismatch between specificity and sensitivity. The ACR uses RF as a biomarker that can be detected in $70-80 \%$ of patients with RA, but it can also be found in other rheumatic diseases. Therefore, it is a test for a non-specific biomarker, which is also present in infections and about $5-10 \%$ of healthy individuals (Birch and Bhattacharya, 2010; Ryu et al., 2011). The CRP test is based on the increase in serum C-reactive protein, which is synthesized in great amounts immediately after any tissue damage. Thus, CRP test is not specific and it is elevated in all inflammatory and infectious processes as well as in the RA. Elevated plasma levels are detected within 4 to 6 hours after injury and peak levels are found after 24 to 72 hours (Otterness, 1994). ACPA antibody is considered the most specific marker for RA, but the sensitivity is not greater than 70\% (Cai et al., 2011).

Another possibility for early diagnosis is the antiperinuclear factor (APF) antibody, which was originally described by Nienhius et al. (1964) by indirect immunofluorescence technique. APF is an autoantibody that reacts against antigens present in keratohyalin granules of human oral mucosa. APF is distributed predominantly around the nucleus of keratinocytes (Vander Cruyssen et al., 2005). High levels of APF are considered specific for RA and the molecular characterization of these antigens resulted in the discovery of citrullinated peptides. From this characterization, enzyme immunoassays for antibodies to citrullinated peptide are produced commercially (ACPA) by ELISA method. These new laboratory tests combined with imaging methods such as ultrasound and magnetic resonance imaging of affected joints have largely contributed to the early diagnosis, which is very important to improve patient's quality of life (Hsin-Hua et al., 2010; Narváez et al., 2008; Nienhius et al., 1964; Østergaard et al., 2008). However, most immunochemical assays for anti-CCP (ELISA) and APF have limited utility for routine clinical practice due to the complexity of procedures and the need for qualified technicians (Liao et al., 2011; Santos et al., 1997).

The several medications administrated to RA patients lead to changes in the serum composition. The persistent and progressive inflammation of the synovial tissue causes joint destruction, affecting mainly the hands (Waljee and Chung, 2011). To try to combat or reduce the loss caused by this disease, the medical community makes use of nonsteroidal anti-inflammatory drugs (NSAID) and low-dose glucocorticoids, associated with modifying antirheumatic drugs (DMARDs) (Elefant et al., 2010; Mouterde et al., 2011).

Nevertheless, the negative sides effects of steroids are a limiting factor, and the dose must be the lowest possible to achieve therapeutic benefit. NSAIDs should not be used alone, as they do not change the course of the disease. Most RA treatment includes NSAIDs for pain control, glucocorticoids and the initiation of a DMARDs (Birch and Bhattacharya, 2010).

Fourier Transform Infrared Spectroscopy (FTIR) analysis has the potential to provide rapid results and may be adapted for a clinical test with high values of sensitivity and specificity (Carvalho et al., 2011; Naumann, 2008; Raniero et al., 2011). In this article, FTIR (Petibois et al., 1999; Sankari et al., 2010) was used as tool to investigate sera of RA and normal (N) individuals, using Partial Least Square (PLS) regression analysis (Muñoz de la Peña et al., 2007). The results were compared to different laboratory techniques such as CRP, RF, anti-CCP, APF. In addition, we also analyzed possible interference of medication and food in the two evaluated groups.

\section{Methods}

This work was approved by the Ethics Committee of the Institute of Research and Development (IP\&D), University of Vale do Paraíba (UniVap) following the Guidelines and Norms Regulating Research involving human, H119CEP/2010.

Selection of the volunteers was done through a questionnaire with information about diet, medications, lifestyle, and the most recent meal. The parameters of exclusion and inclusion were pre-adjusted for both groups. The healthy group was comprised only of women from 30 to 60 years old, due to the predominance of the disease in women, and the disease group was formed by women with confirmed RA diagnosis, according to criteria established by the ACR 2010. 


\section{Blood samples}

The 94 blood samples were collected at UNIFESP (Federal University of São Paulo) and the Department of Hemotherapy and Hematology of São José dos Campos, in agreement with requirements and recommendations of Brazilian Society of Clinical Pathology (SBPC)/Laboratory of Medicine for venous blood (Andriolo et al., 2009). Of the blood samples, 47 were from patients with RA (chronic phase and with long-term drug therapy) and 47 from healthy subjects. The procedure adopted for collecting venous blood was as follows: 1) Collection of whole blood in the antecubital region of the right arm using venipuncture; 2) Storage in sterile tube, gel-barrier vacuum (BD Vacutainer SST Advance Tube, $5 \mathrm{~mL}$, Gold) for 30 min at room temperature; 3) Centrifugation at $4000 \mathrm{~g}$ for $6 \mathrm{~min}$; and 4) Separation of serum, that was stored in polypropilene tubes and placed in sealed polypropylene styrene boxes for transportation and storage of the material at $-23{ }^{\circ} \mathrm{C}$.

\section{Clinical analysis}

The analysis of rheumatoid factor and C-reactive protein were started immediately after the blood collection. RF and CRP were evaluated by latex agglutination test (Wama Diagnóstica ${ }^{\circledR}$ ), based on indirect agglutination of latex particles coated with human IgG and monoclonal anti-CRP antibody, respectively.

The sensitivity of the tests corresponded to $8 \mathrm{Ul} /$ $\mathrm{ml}$ for RF and $6 \mathrm{mg} /$ liter for CRP. The tests for APF (antiperinuclear factor) and ACPA 2nd generation were performed at Rheumatology Division at Escola Paulista de Medicina. The determination of ACPA2 was done using Quanta LiteTM CCP2 IgG Elisa, kit (INOVA Diagnostics, Inc., San Diego, CA, USA), according to the manufacturer's instructions, which set the cut off at $20 \mathrm{U} / \mathrm{ml}$. ACPA titers between 20 and $39 \mathrm{U} / \mathrm{ml}$ were considered weakly positive, between 40 and $59 \mathrm{U} / \mathrm{ml}$ as moderately positive, and $\geq 60 \mathrm{U} / \mathrm{ml}$ as strongly positive. APF was determined as described by Hoet et al. (1991) with slight modifications as established in Brazil by Santos et al. (1997).

\section{Medications and diet}

The drugs used in the RA group were nonbiological and biological. The non-biological DMARDs were Methotrexate (MTX), leflunomide, hydroxychloroquine, sulfazalasine, and cyclosporine. The biological medications are divided in subgroup such as: 1) TNF blockers: Adalimumab, etanercept, and infliximab; 2) Depletors B lymphocytes: Rituximab; 3) Modulators of co-stimulation: Abatacept. For pain control and inflammation of the joints, nonsteroidal anti-inflammatory drugs (NSAIDs) were used alone or combined with low doses of glucocorticoids (up to $15 \mathrm{mg}$ of prednisone) (Bértolo et al., 2007). In the $\mathrm{N}$ group, the only drugs allowed were anti-hypertensives and oral hormone replacement therapy.

The information about the most recent meal from RA and $\mathrm{N}$ groups was evaluated through the TACO table (Brazilian Table of Food Composition). The TACO Table contains the information about the composition of Brazilian foods (Universidade..., 2011). This table was prepared by the Center for Studies and Research in Food (NEPA- UNICAMP) and approved by the National Agency for Sanitary Vigilance.

\section{Fourier Transform Infrared Spectroscopy}

A thin serum film was made with a drop $(1 \mu \mathrm{l})$ of the samples deposited on calcium fluoride $\left(\mathrm{CaF}_{2}\right)$ window and dried using an Eppendorf Concentrator 5301. The spectra of the samples were recorded in the range of 4000-900 $\mathrm{cm}^{-1}$, with 64 scans and a spectral resolution of $4 \mathrm{~cm}^{-1}$, using a FTIR spectrometer (Perkin-Elmer, Spotlight 400). The spectra were collected using the single detector mode of the microscope. To analyze spectral data, the spectrum Image, Spotlight 400 Software, version 3.6.2 was used.

\section{Statistical analysis}

The values obtained through the questionnaire were evaluated, consolidated, and tabulated using a binomial distribution by the statistic software IBM SPSS ${ }^{\circledR}$ 19.0.

PLS analysis was constructed from serum proteins known as bovine serum albumin (BSA) and human immunoglobulin M class (IgM) antibodies, which were purchased from Sigma Aldrich. The human and bovine albumins have very similar primary structures, both being widely used in biochemical and biophysical studies (Gelamo and Tabak, 2000). From the spectroscopic view point, an important difference between these proteins is that the albumin has only one tryptophan residue (Trp214) and bovine albumin possesses two tryptophan residues (Trp134 and Trp212) (Cheng, 2012).

\section{Results}

Figure 1 shows the sensitivity and specificity values of CRP, RF, APF, and ACPA analysis for N and RA groups. The RF and CRP analysis were performed for both groups. However, the APF and ACPA were done only for RA group due to high specificity of RA diagnosis (Lutteri et al., 2007; Santos et al., 1997; Swart et al., 2012). All tests have shown high values of specificity, but there are many differences on sensitivity, which will be remarked upon later in this text. 


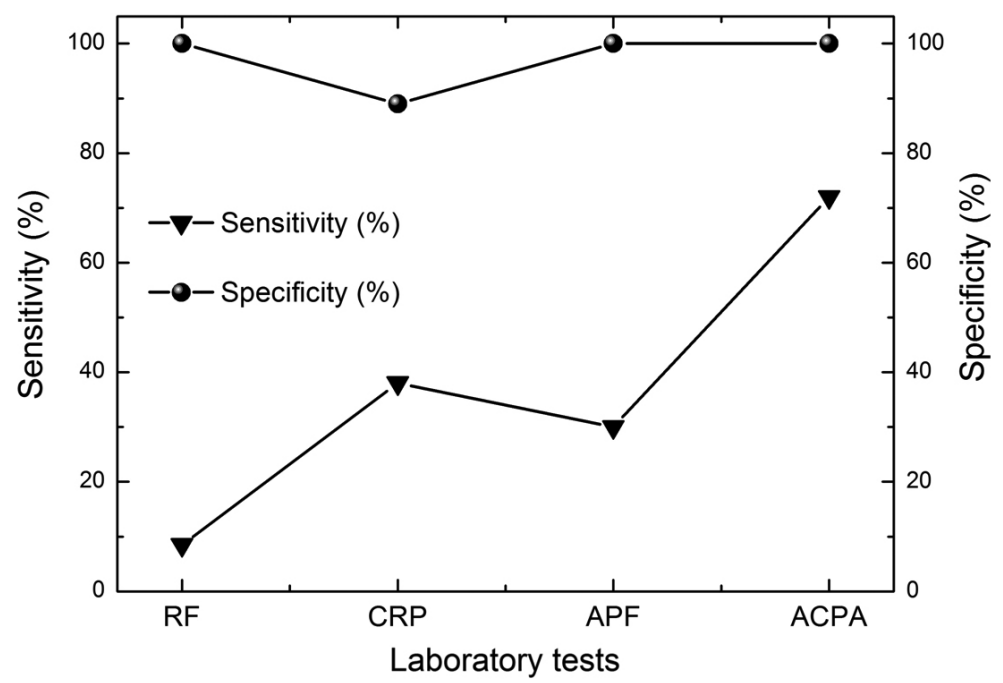

Figure 1. Sensitivity and specificity values of laboratory tests.

\section{Risk factors, diet, and medications}

Table 1 shows the prevalence of smoking, physical activity and nutrition of $\mathrm{N}$ and RA groups. The values $\mathrm{p} \leq 0.05$ indicate significant differences between the variables, a fact apparent in both $\mathrm{N}$ and RA groups. By identifying such similarities, it is possible to correlate the variations found in both groups. Initially it was found that the role of smoking in the inflammatory process is still the subject of study.

The positive reactions of RF and ACPA antibodies in RA patients were compared in smokers, ex-smokers, and non-smokers, with 24 non-smokers and 23 smokers or ex-smokers. The frequency of positive ACPA assay was similar in both RA subgroups $(66.7 \%$ and $78.3 \%$ with a difference of $11.6 \%$ respectively). A positive RF assay was $4.2 \%$ for non-smokers and $13 \%$ for smokers or ex-smokers, with a difference of $8.8 \%$.

With respect to physical activity, both groups had a sedentary lifestyle with $\mathrm{p}<0.05$, showing that most of the population studied did not practice regular physical activity.

The statistic results of food taken in the most recent meal found a higher cholesterol level for rheumatic patients compared to normal individuals. However, with respect to other variables both groups showed similar variations, with $\mathrm{p}<0.05$, demonstrating a percentage intra-group fairly heterogeneous.

Table 2 shows the most used medications for rheumatic and healthy individuals in this study. Methotrexate, leflunomide, and prednisone are among the most widely prescribed rheumatics drugs due to their clinical efficacy and low toxicity. In both groups, the use of antihypertensive drugs is present.

\section{Partial Least Square analysis}

Figure 2 shows the frequency in serum concentration of IgM and BSA of the rheumatic and normal groups. The normal individuals have values ranging from 2.4 to 4.0, while rheumatic individuals vary from 2.6 to 4.2.

\section{Discussion}

Our study suggests that even after long-term drug therapy $(9 \pm 7.9$ years $)$, the biomarker ACPA is still present in the circulatory system of rheumatic individuals. This autoantibody showed high specificity and less sensitivity (see Figure 1). Similarly, Swart et al. (2012) evaluated rheumatic patients (disease duration 8.5 years) using the same ACPA 2nd generation kit, and obtained the following values of sensitivity/ specificity (77.3/98.1\%). Van Venrooij et al. (2006) report that the sensitivity of the test ranges between $60 \%$ (early RA) and 77\% (established RA). The ACPA positive patients usually remain positive despite treatment, and slight declines or even an increase the titers of ACPA may occur (Niewold, 2007). These differences make it impossible to confirm the effectiveness of anti-rheumatic medications on stability/reduction of this autoantibody. The use of this biomarker in the monitoring of rheumatic patients during treatment or their relation to disease activity is still controversial and unexplored. Currently, it is necessary to standardize evaluative concepts, such as: 1) monitoring of biomarkers before and during the course of the disease; 2) detailing of the medications; and 3 ) evaluation of clinical and functional signs. Although the ACPA is more specific for RA, it does not exclude the diagnosis of other autoimmune diseases 
Table 1. Percentage values (\%) of smokers, individuals who practice physical activity (at least 3 times per week), and food intake before the venous blood test in N and RA groups. Source: Universidade Estadual de Campinas (2011) (Anvisa/Ministry of Health).

\begin{tabular}{|c|c|c|c|c|c|c|}
\hline \multirow{2}{*}{ Variables } & \multicolumn{3}{|c|}{ N (\%) } & \multicolumn{3}{|c|}{ RA (\%) } \\
\hline & Yes & No & $\mathbf{p}$ & Yes & No & $\mathbf{p}$ \\
\hline Smokers & 19 & 81 & $* 0.000$ & 15 & 85 & $* 0.000$ \\
\hline Physical activity & 32 & 68 & $* 0.019$ & 28 & 72 & $* 0.03$ \\
\hline Fasting & 0 & 100 & $* 0.000$ & 13 & 87 & $* 0.000$ \\
\hline Lipids & 70 & 30 & $* 0.008$ & 68 & 32 & $* 0.019$ \\
\hline Cholesterol & 15 & 85 & $* 0.000$ & 64 & 36 & 0.079 \\
\hline Saturated & 74 & 26 & $* 0.001$ & 68 & 32 & $* 0.019$ \\
\hline Monounsaturated & 74 & 26 & $* 0.001$ & 68 & 32 & *0.019 \\
\hline Polyunsaturated & 74 & 26 & $* 0.001$ & 68 & 32 & $* 0.019$ \\
\hline Carbohydrate & 83 & 17 & $* 0.000$ & 87 & 13 & $* 0.000$ \\
\hline Proteins & 79 & 21 & $* 0.000$ & 70 & 30 & $* 0.008$ \\
\hline
\end{tabular}

$*_{\mathrm{p}}<0.05$ in relation to the intra-group differences.
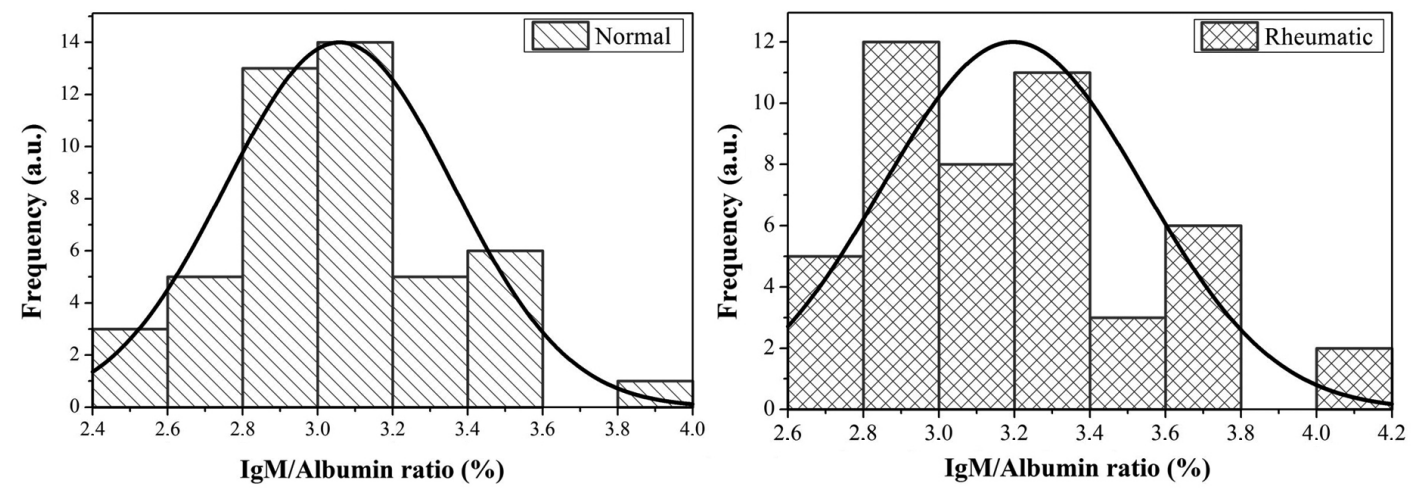

Figure 2. Differences of IgM/Albumin ratio for RA and N groups by PLS.

Table 2. Medications commonly used by the rheumatism and normal groups.

\begin{tabular}{llccc}
\hline \multicolumn{1}{c}{ Medications } & Yes & Not & p \\
\hline Methotrexate & 64 & 36 & 0.079 \\
Prednisone & 55 & 45 & 0.560 \\
Leflunomide & 26 & 74 & $* 0.001$ \\
Chloroquine & 13 & 87 & $* 0.000$ \\
Adalimumab & 11 & 89 & $* 0.000$ \\
Sulfasalazine & 09 & 91 & $* 0.000$ \\
RA group & Hydroxychloroquine & 06 & 94 & $* 0.000$ \\
& Etanercept & 06 & 94 & $* 0.000$ \\
& Infliximab & 04 & 96 & $* 0.000$ \\
& Rituximab & 02 & 98 & $* 0.000$ \\
& Abatacept & 02 & 98 & $* 0.000$ \\
& Cyclosporine & 02 & 98 & $* 0.000$ \\
& Antihypertensives & 47 & 53 & 0.771 \\
& NSAIDs & 19 & 81 & $* 0.000$ \\
\hline N group & Hormones (T4) & 08 & 92 & $* 0.000$ \\
& Contraceptive & 21 & 79 & $* 0.000$ \\
Antihypertensive & 06 & 94 & $* 0.000$ \\
\hline
\end{tabular}

$* \mathrm{p}<0.05$ in relation to the intra-group differences. (psoriatic arthritis, systemic lupus, and Sjögren's syndrome) (Vander Cruyssen, 2005).

In the present study, the high specificity and reduced sensitivity found in the RF analysis may be due to the low sensitivity of our method by indirect agglutination. Swart et al. (2012) and Liao et al. (2011) observed a higher sensitivity and lower specificity of RF (65.2/89.6\% and 67.4/84.3\%) by turbidimetry and nephelometry analysis, respectively. This variation can be attributed to the choice of technique used. Nevertheless, the specificity and sensitivity of RF have been improved by the development of enzymelinked immunosorbent assays (ELISA), which permit the detection and quantitative measurement of RF of various IgG-, IgA-, and IgM-RF class immunoglobulins (Vallbracht and Helmke, 2005). The more specific techniques for testing these classes by ELISA are nephelometry and turbidimetry with $90 \%$ sensitivity (Firestein et al., 2009). However, discrepancies in the values of RF measurements are widely found (Van der Linden et al., 2011). Recent data suggest that IgM-RF as well as other RFs play an important role in the pathogenesis of rheumatoid arthritis, thus 
being one of the more frequently used RFs in research (Ahmed et al., 2010; Zavala-Cerna et al., 2008). ACPA has a specificity of (91-98\%), which is more specific than RF (Romic et al., 2009; Ryu et al., 2011). The ACPA and RF biomarkers are distinct, but are complementary tools to investigate RA.

The CRP and RF values are similar to those described in the literature by indirect agglutination (Carvalho et al., 2011). Our findings show a decrease in sensitivity values of CRP, which suggests a stabilization of disease activity and joint destruction. In general, improvement in CRP levels indicates that a drug has produced a beneficial effect and may be useful for monitoring effects of therapy (Otterness, 1994).

The APF analysis had a lower sensitivity compared to with CRP tests. Cordonnier et al. (1996) investigated the APF marker in individuals with RA for a period of 24 months, obtaining a sensitivity/specificity of $28.6 / 95 \%$. Approximately $50 \%$ of patients with RA early-onset and FR-negative ( $<2$ years) have APF positive and sensitivity/specificity of 59/95\% (Santos et al., 1997). The results shown are consistent with the current literature. Other studies correlating this biomarker with advanced RA could not be found.

Table 1 illustrates some risk factors such as smoking and physical inactivity. Our study shows an involvement of smoking in the aggravation of the positivity of RF and ACPA rheumatic markers. However, the role of smoking in the inflammatory process is still unknown. Goeldner et al. (2011) verified that smoking influences the frequency of ACPA2 positivity, increasing by 2.7 times the risk for high titer ACPA. In addition, they observed that the females exposed to tobacco had this rate 7.7 times increased compared to men. Alsalahy et al. (2010) also claims that the levels of ACPA and RF are higher in smokers. Arnson et al. (2010) described that cigarette smoking affects the immune system in diverse ways, both increasing inflammatory allergic and autoimmune reactions, and decreasing systemic activity against infections. Smokers with RA have a disease characterized by a greater proportion of autoantibody positivity. This emphasizes the importance of prevention/eradication of its use in order to avoid respiratory complications and autoimmune conditions.

The $\mathrm{N}$ and RA groups presented similar characteristics in relation to physical activity, being composed of large number of sedentary individuals. Plasqui (2008) describes that exercise contributes to the improvement of aerobic conditioning and stretching. Consequently, the quality of life and activities of daily living are improved. Furthermore, exercise does not cause deleterious effects on the health of the rheumatoid patient, i.e., it does not increase pain conditions, disease progression, or joint damage. Benhamou et al. (2007) warns that prolonged bed rest in patients with RA may lead to deconditioning and functional decline. In contrast, more detailed investigations about the role of physical activity on the progression of RA should be conducted.

In relation to eating, an important challenge for the present methodology is sample standardization, because serum carries several relevant components, such as protein, lipids, vitamins, carbohydrates, etc. The concentrations of each of these are not constant, but depend on the diet content, interval between meals and sample collection, medications, hormone cycles, genetic factors, metabolic activity, etc. Among this enormous variation, the main objective is to identify biomarkers that could reliable correlate to relevant clinical parameters despite the influence of extraneous factors. Many experts describe the high potential of the infrared technique to diagnose different diseases from serum, but the influences of the above mentioned extraneous factors in spectral interpretation is still largely unknown (Déléris and Petibois, 2003; Petibois et al., 2001; Staib et al., 2001).

The current study presents the most used medications for treating rheumatism, especially methotrexate $(64 \%)$ and prednisone $(55 \%)$. Alarcón et al. (1990) reports that MTX causes a suppression of rheumatoid factors class $\mathrm{A}$ and $\mathrm{M}$ immunoglobulin in human serum, which leads to a decrease of these autoantibodies in all patients who used the drug. Bathon et al. (2000) describes that MTX reduced disease activity, and this correlated with the absence of progressive radiographic evidence. Lipsky et al. (2000) also reports that MTX associated with infliximab significantly improved clinical benefit and radiographic progression stops. Klaasen et al. (2011) demonstrates that therapy with infliximab reduces the levels of RF and ACPA antibodies after 16 weeks of treatment, which was also confirmed in our results for patients with lowest treatment time, 13 months. Other drugs such as adalimumab and etanercept, also known as biologic DMARDs or TNF blockers, and non-biological DMARDs also showed similar effects, with reduced levels of RF and ACPA throughout drug treatment (Atzeni et al., 2006; Fries et al., 1996). Thus, the lowest values of autoantibodies were evidenced by efficient treatment through stabilization of immune activities. However, a long period of autoantibodies suppression can lead to a hazardous situation of infections (Ateș et al., 2007). Glucocorticoids are frequently associated with the described medications above, because prednisone exerts potent inhibitory effects on transcription and action of cytokines (IL-1 $\beta$, IL-2, IL-3, IL-6, TNF- $\alpha$, 
interferon- $\gamma$, T helper type 1 (Th1), and granulocyte macrophage colony-stimulating factor), which act in the pathogenesis of RA (Ryu et al., 2011), but little effect was observed in the immunoglobulin synthesis. Boumpas et al. (1993) report that unlike $\mathrm{T}$ cells, B lymphocytes are relatively resistant to the immunosuppressive effects of glucocorticoids. Consequently, low dose glucocorticoids are not expected to affect immunoglobulin levels or synthesis of antibodies in the serum.

In the normal group, the used medications are those associated with aging, contraceptives drugs, and hormone replacement. Hypertension is a fairly common disorder and its prevalence is primarily determined by age and ethnicity (Elliott, 2006). Lind et al. (1994) found that the long-term use of antihypertensive drugs does not affect serum lipid levels. Nevertheless, a detailed study of such intakes was not done, because just a qualitative survey was applied.

Finally, the PLS method may indicate that the rheumatic group had higher elevation in serum levels of IgM and/or albumin compared to the normal group. These results are also supported by other authors, which showed the potential of PLS model associated with infrared spectroscopy, helping determine concentrations of HSA (human serum albumin) and gammaglobulin (Kasemsumran et al., 2003; Perez-Guaita et al., 2013).

Our work supports other similar studies that have endeavored to demonstrate that FTIR spectroscopy by PLS method may be of interest as a diagnostic tool, determining not only biomolecules such as proteins, lipids, and gammaglobulins, but also helping to identify changes in molecular composition and structure of chemical entities. Moreover, the clinical analysis of biomarkers showed that even after long-term drug therapy, the ACPA is the most specific and sensitive to monitor the progress of RA. Finally, the influence of medication and eating on both spectral analyzes was discussed. In addition to the possible influence of risk factors such as smoking, the increased levels of ACPA in rheumatic individuals stand out.

\section{Acknowledgements}

The authors would like to thank all voluntaries and the financial support given by CNPQ (Project 301022/2012-7) and CAPES for the master fellowship. The authors also thank Alene Alder-Rangel for reviewing the English.

\section{References}

Alarcón GS, Schrohenloher RE, Bartolucci AA, Ward JR, Williams HJ, Koopman WJ. Supression of rheumatoid factor production by methotrexate in patients with rheumatoid arthritis. Evidence for differential influences of therapy and clinical status on IgM and IgA rheumatoid factor expression. Arthritis and Rheumatism. 1990; 33(8):1156-61. http:// dx.doi.org/10.1002/art.1780330816

Aletaha D, Neogi T, Silman AJ, Funovit SJ, Felson DT, Bingham CO, Birnbaum NS, Burmester GR, Bykerk VP, Cohen MD, Combe B, Costenbader KH, Dougados M, Emery P, Ferraccioli G, Hazes JMWH, Hobbs K, Huizinga TWJ, Kavanaugh A, Kay J, Kvien TK, Laing T, Mease P, Ménard HA, Moreland LW, Naden LR, Pincus T, Smolen JS, Stanislawska-Biernat E, Symmons D, Tak PP, Upchurch KS, Vencovsky J, Wolfe F, Hawker G. Rheumatoid arthritis classification criteria. Arthritis \& Rheumatism. 2010; 62(9):2569-81. http://dx.doi.org/10.1002/art.27584

Ahmed MM, Obaid Al-Ruhaimi KA, Mohammed SH. Evaluation of the rheumatoid factors of the IgG, IgM and IgA isotypes as prognostic parameters for rheumatoid arthritis among Iraqi patients. Indian Journal of Pathology \& Microbiology. 2010; 53(3):433-8. http://dx.doi. org/10.4103/0377-4929.68265

Alsalahy MM, Nasser HS, Hashem MM, Elsayed SM. Effect of tobacco smoking on tissue protein citrullination and disease progression in patients with rheumatoid arthritis. Saudi Pharmaceutical Journal. 2010; 18(2):75-80. http:// dx.doi.org/10.1016/j.jsps.2010.02.002

Andriolo A, Martins AR, Ballarati CAF, Barbosa IV, Mendes MA, Melo MR, Sumita NM, Romano P, Trindade PA. Recomendações da Sociedade Brasileira de Patologia Clínica / Medicina Laboratorial para coleta de sangue venoso. 2th ed. São Paulo: Manole Ltda; 2009. p. 16-85. Available from: http://www.sbpc.org.br/upload/conteudo/320090814145042. pdf.

Arnson Y, Shoenfeld Y, Amital H. Effects of tobacco smoke on immunity, inflammation and autoimmunity. Journal of Autoimmunity. 2010; 34(3):J258-65. http://dx.doi. org/10.1016/j.jaut.2009.12.003

Ateş A, Karaaslan Y, Aksaray S. Predictive value of antibodies to cyclic citrullinated peptide in patients with early arthritis. Clinical Rheumatology. 2007; 26(4):499-504. http://dx.doi. org/10.1007/s10067-006-0309-Z

Atzeni F, Sarzi-Puttini P, Dell'Acqua D, De Portu S, Cecchini G, Cruini C, Carrabba M, Meroni PL. Adalimumab clinical efficacy is associated with rheumatoid factor and anti-cyclic citrullinated peptide antibody titer reduction:one-year prospective study. Arthritis Research \& Therapy. 2006; 8(1):1-8. http://dx.doi.org/10.1186/ar1851

Bathon JM, Martin RW, Fleischmann RM, Tesser JR, Schiff MH, Keystone EC, Genovese MC, Wasko MC, Moreland LW, Weaver AL, Markenson J, Finck BK. A comparison of etanercepte and methotrexate in patients with early rheumatoid arthritis. New England Journal of Medicine. 2000; 343(22):1586-93. http://dx.doi.org/10.1056/ NEJM200011303432201

Benhamou MAM. Reconditioning in patients with rheumatoid arthritis. Annales de Réadaptation et de Médecine Physique. 2007; 50(6):382-5. http://dx.doi.org/10.1016/j. annrmp.2007.03.023 
Bértolo MB, Brenol CV, Schainberg CG, Neubarth F, Lima FAC, Laurindo IM, Silveira IG, Pereira IA, Loures MAR, Azevedo MN, Freitas MVC, Neto MSP, Xavier RM, Giorgi RDN, Kowalski SC, Anti SMA. Atualização do consenso brasileiro no diagnóstico e tratamento da artrite reumatóide. Revista Brasileira de Reumatologia. 2007; 47(3):151-9.

Birch JT, Bhattacharya S. Emerging trends in diagnosis and treatment of rheumatoid arthritis. Primary Care: Clinics in Office Practice. 2010; 37(4):779-92. http://dx.doi. org/10.1016/j.pop.2010.07.001

Boumpas DT, Chrousos GP, Wilder RL, Cupps TR, Balow JE. Glucocorticoid therapy for immune-mediated diseases: Basic and clinical correlates moderator. Annals of Internal Medicine. 1993; 119(12):1198-208. http://dx.doi.org/10.7326/00034819-119-12-199312150-00007

Cai B, Wang L, Liu J, Feng W. Performance evaluation of Elecsys analysis system for anti-cyclic citrullinated peptide detection in comparison with commercially available ELISA assays in rheumatoid arthritis diagnosis. Clinical Biochemistry. 2011; 44(12):989-93. http://dx.doi. org/10.1016/j.clinbiochem.2011.05.021

Carvalho CS, Martin AA, Santo AME, Andrade LEC, Pinheiro MM, Cardoso MAG, Raniero L. A rheumatoid arthritis study using raman spectroscopy. Theoretical Chemistry Accounts. 2011; 130(4-6):1211-20. http://dx.doi. org/10.1007/s00214-011-0905-0

Centers for Disease Control - CDC, Prevention National Center for Chronic Disease Prevention and Health Promotion. Division of Adult and Community Health. Arthritis meeting the challenge. At a glance 2011 [internet]. 2012 Oct [cited 2013 Oct 30]. Available from: http://www.cdc. gov/chronicdisease/resources/publications/aag/pdf/2011/ Arthritis-AAG-2011-508.pdf.

Cheng Z. Interaction of ergosterol with bovine serum albumin and human serum albumin by spectroscopy analysis. Molecular Biology Reports. 2012; 39(10):9493-508. http:// dx.doi.org/10.1007/s11033-012-1814-6

Cheng YJ, Hootman JM, Murphy LB, Langmaid GA, Helmick CG. Prevalence of doctor-diagnosed arthritis and arthritis-attributable activity limitation - United States 2007-2009. Morbidity and Mortality Weekly Report. 2010; 59(39):1261-5.

Cordonnier C, Meyer O, Palazzo E, De Bandt M, Elias A, Nicaise P, HaÏm T, Kahn MF, Chatellier G. Diagnostic value of anti-ra33 antibody, antikeratin antibody, antiperinuclear factor and antinuclear antibody in early rheumatoid arthritis: comparison with rheumatoid factor. British Journal of Rheumatology. 1996; 35(7):620-4. http://dx.doi.org/10.1093/ rheumatology/35.7.620

Déléris G, Petibois C. Applications of FT-IR spectrometry to plasma contents analysis and monitoring. Vibrational Spectroscopy. 2003; 32(1):129-36. http://dx.doi.org/10.1016/ S0924-2031(03)00053-5

Desai SP, Januzzi JL, Pande AN, Pomerantsev EV, Resnic FS, Fossel A, Chibnik LB, Solomon DH. Comparison of symptoms, treatment, and outcomes of coronary artery disease among rheumatoid arthritis and matched subjects undergoing percutaneous coronary intervention. Seminars in Arthritis and Rheumatism. 2010; 40(3):215-21. http:// dx.doi.org/10.1016/j.semarthrit.2010.04.002

Duquerroy S, Stura EA, Bressanelli S, Fabiane SM, Vaney MC, Beale D, Hamon M, Casali P, Rey FA, Sutton BJ, Taussig MJ. Crystal structure of a human autoimmune complex between IgM rheumatoid factor RF61 and IgG1 Fc reveals a novel epitope and evidence for affinity maturation. Journal of Molecular Biology. 2007; 368(5):1321-31. http:// dx.doi.org/10.1016/j.jmb.2007.02.085

Ebringer A, Rashid T, Wilson C. Rheumatoid arthritis, proteus, anti-CCP anibodies and Karl Popper. Autoimmunity Reviews. 2010; 9(4):216-23. http://dx.doi.org/10.1016/j. autrev.2009.10.006

Elefant E, Cournot MP, Beghin D, Vauzelle C. Rheumatology drugs and pregnancy. Joint Bone Spine. 2010; 77(6):506-10. http://dx.doi.org/10.1016/j.jbspin.2010.09.007

Elliott H. Epidemiology, aetiology and prognosis of hypertension. Medicine. 2006; 34(8):286-9. http://dx.doi. org/10.1053/j.mpmed.2006.06.002

Filipovic I, Walker D, Forster F, Curry AS. Quantifying the economic burden of productivity loss in rheumatoid arthritis. Rheumatology (Oxford). 2011; 50(6):1083-90. http://dx.doi.org/10.1093/rheumatology/keq399

Firestein GS, Budd RC, Harris ED, McInnes IB, Ruddy S, Sergent JS. Kelley's textbook of rheumatology. 5th ed. Philadelphia: Saunders Elsevier; 2009. p. 755-62.

Fries JF, Williams CA, Morfeld D, Singh G, Sibley J. Reduction in long-term disability in patients with rheumatoid arthritis by disease-modifying antirheumatic drug-based treatment strategies. Arthritis and Rheumatism. 1996; 39(4):616-22. http://dx.doi.org/10.1002/art.1780390412

Gelamo EL, Tabak M. Spectroscopic studies on the interaction of bovine (BSA) and human (HSA) serum albumins with ionic surfactants. Spectrochimica Acta Part A Molecular Biomolecular Spectroscopy. 2000; 56(11):2255-71. http:// dx.doi.org/10.1016/S1386-1425(00)00313-9

Goeldner I, Skare TL, Reason ITM, Nisihara RM, Silva MB, Utiyama SRR. Association of anticyclic citrullinated peptide antibodies with extra-articular manifestations, gender, and tabagism in rheumatoid arthritis patients from southern Brazil. Clinical Rheumatology. 2011; 30(7):975-80. http:// dx.doi.org/10.1007/s10067-011-1711-8

Hambright D, Henderson RA, Cook C, Worrel T, Moorman CT, Bolognesi MP. A comparison of perioperative outcomes in patients with and without rheumatoid arthritis after receiving a total shoulder replacement arthroplasty. Journal of Shoulder and Elbow Surgery. 2011; 20(1):77-85. http:// dx.doi.org/10.1016/j.jse.2010.03.005

Haro I, Gómara MJ, Pérez ML, Viñas O, Ercilla G, GómezPuerta JA, Sanmartí R. Antibodies against B-fibrin synthetic peptides: A study of their association with the immunogenetic background and disease course of rheumatoid arthritis patients. European Journal of Medicinal Chemistry. 2011; 46(4):1095-102. http://dx.doi.org/doi: 10.1016/j. ejmech.2011.01.024 
Hsin-Hua C, Der-Yuan C, Tsu-Yi H, Guo-Dung H, Howard HCL, Chia-Wei H, Joung-Liang L. Predicting the progression of palindromic rheumatism to rheumatoid arthritis: The role of ultrasonography and anti-cyclic citrullinated peptide antibodies. Journal of Medical Ultrasound. 2010; 18(1):1726. http://dx.doi.org/10.1016/S0929-6441(10)60003-3

Hoet RM, Voorsmit RA, Van Venrooij WJ. The perinuclear factor, a rheumatoid arthritis-specific autoantigen, is not present keratohyalin granules of cultured buccal mucosa cell. Clinical and Experimental Immunology. 1991; 84(1):5965. http://dx.doi.org/10.1111/j.1365-2249.1991.tb08124.x

Karlson EW, Deane K. Environmental and gene-environment interactions and risk of rheumatoid arthritis. Rheumatic Diseases Clinics of North America. 2012; 38(2):405-26. http://dx.doi.org/10.1016/j.rdc.2012.04.002

Kasemsumran S, Du YP, Murayama K, Huehne M, Ozaki Y. Simultaneous determination of human serum albumin, $\gamma$-globulin, and glucose in a phosphate buffer solution by near-infrared spectroscopy with moving window partial least-squares regression. Analyst. 2003; 128(12):1471-7. http://dx.doi.org/10.1039/b307294k

Klaasen R, Cantaert T, Wijbrandts CA, Teitsma C, Gerlag DM, Out TA, de Nooijer MJ, Baeten D, Tak PP. The value of rheumatoid factor and anti-citrullinated protein antibodies as predictors of response to infliximab in rheumatoid arthritis: an exploratory study. Rheumatology (Oxford). 2011; 50(8):148793. http://dx.doi.org/10.1093/rheumatology/ker010

Külkamp W, Dario AB, Gevaerd MS, Domenech SC. Artrite reumatóide e exercício físico: resgate histórico e cenário atual. Revista Brasileira de Atividade Física \& Saúde. 2009; 14(1):55-64.

Liao J, Ip WS, Cheung KY, Wan WM, Cautherley GW, Cai $X$, Lin X, Renneberg R, Chan CP. Diagnostic utility of an anti-CCP point-of-care immunotest in Chinese patients with rheumatoid arthritis. Clinica Chimica Acta. 2011; 412(910):778-81. http://dx.doi.org/10.1016/j.cca.2011.01.013

Lind L, Pollare T, Berne C, Lithell H. Long-term metabolic effects of antihypertensive drugs. American Heart Journal. 1994; 128(6):1177-83. http://dx.doi.org/10.1016/00028703(94)90749-8

Lipsky PE, Van der Heijde DM, St Clair EW, Furst DE, Breedveld FC, Kalden JR, Smolen JS, Weisman M, Emery P, Feldmann M, Harriman GR, Maini RN; Anti-tumor necrosis factor trial in rheumatoid arthritis with concomitant therapy study group. Infliximab and methotrexate in the treatment of rheumatoid arthritis. New England Journal of Medicine. 2000; 343(22):1594-602. http://dx.doi.org/10.1056/ NEJM200011303432202

Lutteri L, Malaise M, Chapelle JP. Comparison of second- and third-generation anti-cyclic citrullinated peptide antibodies assays for detecting rheumatoid arthritis. Clinica Chimica Acta. 2007; 386(1-2):76-81. http://dx.doi.org/10.1016/j. cca.2007.08.002

Malaviya AN, Collings JB, Makol A, Kaushik P. Effect of baseline rheumatoid factor (RF) levels on DAS28response to standard DMARD-combination treatment in patients with rheumatoid arthritis (RA). Indian Journal of
Rheumatology. 2009; 4(2):51-5. http://dx.doi.org/10.1016/ S0973-3698(10)60174-4

Martínez EO, Ramírez DFH, Núñez-Álvarez CA, Cabiedes J. Proteínas citrulinadas en artritis reumatoide. Reumatología. Clínica. 2011; 7(1):68-71. http://dx.doi.org/10.1016/j. reuma.2009.09.010

Mouterde G, Baillet A, Gaujoux-Viala C, Cantagrel A, Wendling D, Le Löet X, Schaeverbeke T. Optimizing methotrexate therapy in rheumatoid arthritis: A systematic literature review. Joint Bone Spine. 2011; 78(6):587-92. http://dx.doi.org/10.1016/j.jbspin.2011.01.01

Muñoz de la Peña A, Merás ID, Jiménez GA, Goicoechea HC. Evaluation of unfolded-partial least squares coupled to residual trilinearization for four-way calibration of folic acid and methotrexate in human serum samples. Talanta. 2007; 72(4):1261-8. http://dx.doi.org/10.1016/j.talanta.2007.01.018

Narváez J, Sirvent E, Narváez JA, Bas J, Gómez-Vaquero C, Reina D, Nolla JM, Valverde J. Usefulness of magnetic resonance imaging of the hand versus anticyclic citrullinated peptide antibody testing to confirm the diagnosis of clinically suspected early rheumatoid arthritis in the absence of rheumatoid factor and radiographic erosions. Seminars in Arthritis and Rheumatism. 2008; 38(2):101-9. http://dx.doi. org/10.1016/j.semarthrit.2007.10.012

Naumann D. Vibrational spectroscopy in microbiology and medical diagnostics. In: Lasch P, Kneipp J, editors. Biomedical Vibrational Spectroscopy. John Wiley \& Sons: Canadá; 2008. p. 385. http://dx.doi.org/10.1002/9780470283172.ch1

Nienhius RLF, Mandema E, Smids C. New serum factor in patients with rheumatoid arthritis: the antiperinuclear factor. Annals of the Rheumatic Diseases. 1964; 23(4):302-5. http:// dx.doi.org/10.1136/ard.23.4.302

Niewold TB, Harrison MJ, Paget SA. Anti-CCP antibody testing as a diagnostic and prognostic tool in rheumatoid arthritis. Quarterly Journal of Medicine. 2007; 100:193-201. http://dx.doi.org/10.1093/qjmed/hem015

Raniero L, Canevari RA, Ramalho LNZ, Ramalho FS, Santos EAP, Bitar RA, Jalkanen KJ, Martinho HS, Martin AA. In and ex vivo breast disease study by raman spectroscopy. Theoretical Chemistry Accounts. 2011; 130(4-6):1239-47. http://dx.doi.org/10.1007/s00214-011-1027-4

Ruiz-Esquide V, Sanmartí R. Tobacco and other environmental risk factors in rheumatoid arthritis. Reumatología Clinica. 2012; 8(6):342-50. http://dx.doi.org/10.1016/j. reuma.2012.02.011

Ryu HJ, Takeuchi F, Kuwata S, Kim YJ, Lee EY, Lee EB, Song YW. The diagnostic utilities of anti-agalactosyl IgG antibodies, anti-cyclic citrullinated peptide antibodies, and rheumatoid factors in rheumatoid arthritis. Rheumatolology International. 2011; 31(3):315-9. http://dx.doi.org/10.1007/ s00296-009-1260-5

Okamoto S, Adachi M, Chujo S, Yamada K, Akita K, Itoh S, Takii T, Hayakawa K, Onozaki K. Etiological role of cigarette smoking in rheumatoid arthritis: Nasal exposure to cigarette smoke condensate extracts augments the development of collagen-induced arthritis in mice. Biochemical and 
Biophysical Research Communications. 2011; 404(4):108892. http://dx.doi.org/10.1016/j.bbrc.2010.12.118

Østergaard M, Pederse SJ, Døhn UM. Imaging in rheumatoid arthritis-status and recent advances for magnetic resonance imaging, ultrasonography, computed tomography and conventional radiograph. Best Practice \& Research Clinical Rheumatology. 2008; 22(6):1019-44. http://dx.doi. org/10.1016/j.berh.2008.09.014

Otterness IG. The value of C-Reactive protein measurement in Rheumatoid Arthritis. Seminars in. Arthritis and Rheumatism. 1994; 24(2):91-104. http://dx.doi.org/10.1016/S00490172(05)80003-4

Petibois C, Cazorla G, Cassaigne A, Déléris G. Plasma protein contents determined by Fourier-Transform Infrared Spectrometry. Clinical Chemistry. 2001; 47(4):730-8.

Petibois C, Rigalleau V, Melin AN, Perromat A, Cazorla G, Gin H, Deléris G. Determination of glucose in dried serum samples by Fourier-Transform Infrared spectroscopy. Clinical Chemistry. 1999; 45(9):1530-5.

Perez-Guaita D, Ventura-Gayete J, Pérez-Rambla C, SanchoAndreu M, Garrigues S, De la Guardia M. Evaluation of infrared spectroscopy as a screening tool for serum analysis. Impact of the nature of samples included in the calibration set. Microchemical Journal. 2013; 106:202-11. http://dx.doi. org/10.1016/j.microc.2012.06.016

Plasqui G. The role of physical activity in rheumatoid arthritis. Physiology and Behavior. 2008; 94(2):270-5. http://dx.doi.org/10.1016/j.physbeh.2007.12.012

Romic Z, Unic A, Derek L, Zivkovic M, Marijancevic D, Kes P, Pehar M. Anti-citrullinated protein antibody and rheumatoid factor in patients with end-stage renal disease. Clinical Chemistry and Laboratory Medicine. 2009; 47(8):959-62. http://dx.doi.org/10.1515/CCLM.2009.217

Sankari G, Krishnamoorthy E, Jayakumaran S, Gunasekaran S, Priya VV, Subramaniam S, Subramaniam S, Mohan SK. Analysis of serum immunoglobulins using Fourier Transform Infrared spectral measurements. Biology and Medicine. 2010; 2(3):42-8.

Santos WS, Silva NP, Atra E, Andrade LEC. Diagnostic value of antiperinuclear factor and anti-stratum corneum antibody in rheumatoid arthritis. Revista Brasileira de Reumatologia. 1997; 37(5): 251-9.

Staib A, Dolenko B, Fink DJ, Früh J, Nikulin AE, Otto M, Pessin-Minsley MS, Quarder O, Somorjai R, Thienel U, Werner G, Petrich W. Disease pattern recognition testing for rheumatoid arthritis using infrared spectra of human serum. Clinica Chimica Acta. 2001; 308(1-2):79-89.

Swart A, Burlingame RW, Gürtler I, Mahler M. Third generation anti-citrullinated peptide antibody assay is a sensitive marker in rheumatoid factor negative rheumatoid arthritis. Clinica Chimica Acta. 2012; 414:266-72. http:// dx.doi.org/10.1016/j.cca.2012.09.015

Universidade Estadual de Campinas - UNICAMP. Tabela brasileira de composição de alimentos - TACO [internet]. Campinas: UNICAMP/NEPA; 2011. [cited 2011 Sep 9]. Available from: http://www.unicamp.br/nepa/taco/contar/ taco_4_edicao_ampliada_e_revisada.pdf?arquivo=taco_4 versao_ampliada_e_revisada.pdf.

Vallbracht I, Helmke K. Additional diagnostic and clinical value of anti-cyclic citrullinated peptide antibodies compared with rheumatoid factor isotypes in rheumatoid arthritis. Autoimmunity Reviews. 2005; 4(6):389-94. http://dx.doi. org/10.1016/j.autrev.2005.02.001

Vander Cruyssen B, Peene I, Cantaert T, Hoffman IEA, De Rycke L, Veys EM, De Keyse F. Anti-citrullinated protein/peptide antibodies (ACPA) in rheumatoid arthritis: specificity and relation with rheumatoid factor. Autoimmunity Reviews. 2005; 4(7):468-74. http://dx.doi.org/10.1016/j. autrev.2005.04.018

Van der Linden MP, Batstra MR, Bakker-Jonges LE; Foundation for Quality Medical Laboratory Diagnostics, Detert J, Bastian H, Scherer HU, Toes RE, Burmester GR, Mjaavatten MD, Kvien TK, Huizinga TW, Van der Helmvan Mil AH. Toward a data-driven evaluation of the 2010 American College of Rheumatology/European League against rheumatism criteria for rheumatoid arthritis: Is it sensible to look at levels of rheumatoid factor? Arthritis and Rheumatism. 2011; 63(5):1190-9. http://dx.doi.org/10.1002/ art.30200

Van Venrooij WJ, Zendman AJW, Pruijn GJM. Autoantibodies to citrullinated antigens in (early) rheumatoid arthritis. Autoimmunity Reviews. 2006; 6:37-1. http://dx.doi. org/10.1016/j.autrev.2006.03.008

Zavala-Cerna MG, Nava A, García-Castañeda E, DuránGonzález J, Arias-Merino MJ, Salazar-Páramo M. Serum IgG activity against cyclic citrullinated peptide in patients evaluated for rheumatoid factor correlates with the $\operatorname{IgM}$ isotype. Rheumatology International. 2008; 28(9):851-7. http://dx.doi.org/10.1007/s00296-008-0535-6

Waljee JF, Chung KC. Outcomes research in rheumatoid arthritis. Hand Clinics. 2011; 27(1):115-26. http://dx.doi. org/10.1016/j.hcl.2010.10.005.

\footnotetext{
Authors

Carolina da Silva Carvalho, João Lucas Rangel, Juliana Ferreira-Strixino, Airton Abrahão Martin, Leandro Raniero* Instituto de Pesquisa e Desenvolvimento - IP\&D, Universidade do Vale do Paraíba - UniVap, Av. Shishima Hifumi, 2911, Urbanova, CEP 12244-000, São José dos Campos, SP, Brazil
}

Luiz Eduardo Coelho Andrade, Silene Peres Keusseyan

Divisão de Reumatologia, Departamento de Medicina, Universidade Federal de São Paulo - UniFesp, São Paulo, SP, Brazil 